automatic exp «nsion gear, under the many conditions of working which the author suppos:s; and as the discussion on the paper was adjourned until the next meeting, we may leave the subject for the present.

The summer meeting of this Institution will be held in Glas. gow this year, commencing Tuesday, July 30 , and concluding on the folluwing Friday.

\section{THE ADVANCE OF TECHNICAL} EDUCATION.

THE present state of technical education in England is, on the whole, satisfactory from the scientific point of view The authorities having the fund; arising from the Customs and Excise Act under their control, are beginning to see that in struction in the principles of science is by far the most important of the requirements. They are also coming to recognise that inmediate results cannot be expected from their work-that they are laying a foundation rather than erect. ing a complex editice. The Technical Iustruction Committees who have not sufficiently realised this, will find that they will have to materially modify their at present too ambitious schemes, postponing much of the instrucion in subjects of lechnology until a more thorough acquaintance with the fundamental principles of science underlying all such purely technical education has been provided, for it is only by such means that the stability of their educational sup rstructure can be en iured.

There are no groun's, therefore, for laking a pe-simistic view of the future of technical instruction. One of the most gratify ing signs of development is the large nuinher of scholarship now awarded, and the increase in the number of $\mathrm{c} \cdot \mathrm{mpetitors}$ for them. The current number of the Record of Technical and Secondary Education sets forth in detail a statement as to the scholarships and exhibitions actually awardel, during the year 1893-4, by County and County Boroug i $\mathrm{C}$ uncils. This most valuable Return shows the number of scholar,hips and exhibitions awarded; the value and length of tenure of the award: where held; condition; to be fulfilled by the candidates; the examining bodv, and the subjects of examination. Subjoined is a summary of the information.

\begin{tabular}{|c|c|c|c|c|c|c|}
\hline \multirow{5}{*}{\multicolumn{2}{|c|}{$\begin{array}{l}\text { Scholarships and Exhibitions } \\
\text { tenable at } \\
\text { (1) Technical, and Science } \\
\text { and Art Schools ... } \\
\text { (2) Secondary Schools } \\
\text { (3) Universities or Institu- } \\
\text { tions of University rank } \\
\text { (4) Short courses of instruc- }\end{array}$}} & & & \multicolumn{3}{|c|}{ Exhibitions. } \\
\hline & & $\begin{array}{l}\text { o. of } \\
\text { ancils. }\end{array}$ & & $\begin{array}{l}\text { Number } \\
\text { awarded. }\end{array}$ & & $\begin{array}{l}\text { otal yearly } \\
\text { value. }\end{array}$ \\
\hline & & 36 & $\ldots$ & 3456 & $\ldots$ & 10,620 \\
\hline & & 37 & ... & 1789 & ... & 20,409 \\
\hline & & 28 & .. & 362 & ... & 6,783 \\
\hline tion $\quad \ldots \quad \ldots$ & $\ldots$ & 25 & $\ldots$ & 561 & $\ldots$ & 3,825 \\
\hline & & & & 6168 & & 41,637 \\
\hline
\end{tabular}

Sixty individual counties and county boroughs are represented in the above summary. Two oth $*$ rs, Deriy and Sheffield, allocate respectively $\ell 325$ and $\ell$ roso annually to scholarships, and taking these into consideraion, it appears that the total sum expended for the promotion of technical and secondary education by scholariships, during the year ending March 1894, was, in round numbers, $\complement_{43}, 000$. But this by no means represents the limits of expend ture under the scholarship heid. It does not take the renewal of scholarships into account, and there are still seven local authorities whose scholarship schemes have not come into operation. Also, the scholarship schemes will undoubtedly he further developed as the work goes on; in fact, it is estimated that before very long as much as $£ 30$,000 will be spent annually on scholarships by the London Technical Education Board alone. Truly, these are halcyon days for the promising young student, however humble his state of life may be.

As to the values of the scholarships, they vary from a few shillings, as a fee for a short course of instruction, to $£ 60$ a year tenable for three years. The lower limit of age is usually thirteen, and the higher, twenty-five, though we see no reason why such a maximum age should be made absolu'e. In some cases, the income of the parents of competitors must not exceed $f 400$ a year, but in others-London is the most notable instance-the parents of competitors for junior scholarships must not be in receipt of more than $£$ I 50 a year.
Another important statement in the current Record shows the plans for promoting techiical and second try education in each of the counties and county boroughs of England. From this it appears that, of the 110 loc 11 authorities in England, 96 are giving the whole, and 13 part of their grants to educational purposes. Preston is the remaininy authori $y$, and it devotes the whole of the $g$ ant available-about $£ \mathrm{I} 600$ per year-to the relief of the borough rate. But it should be stated at once, that Pres'on possesses a well-endowed "Harris Institute," where technical education has been carried on for years. The total amount avallable by local authorities is about $£ 744,000$, of which about $£ 144,000$ is diverted to the relief of the rates, leaving $£ 600,000$ for expenditure on education. We are sanguine enough to believe that, before long, most o' the $£ \mathrm{I} 44,000$ at present devoled to general county pu poses will be expend $d$ in advancing technical education. Liniton alone is responsible for $E_{114}, 000$ of this misapplied balance, but as its edtcational scheme matures, it will doubtless absorh the whole am unt avalable. It is to be hoped that the authorities applying the remaining $£ 30$, 000 to rates, will soon see how detrimeatal their action is to their own interests.

In this connection it is nece:sary to condemn the application to rates of any unexpended balance of the grant available. In every county and county bo ough there are person; who utterly fail to realive that the interests of science are the intere:ts of industry. To them, immed ate advantages in the shape of a minute reduction of the rates, appeals far more than prospective developments of our national industries. Had such people the contrel of affairs, technical instruction would indeed be curtailed within narrow limits. Fortunately, they represent but a small minori'y in the County Councils; nevertheless, their influence is occasionally manifest. Ever since the Technical Education Acts came into force, attempts have been made here and there to use for general county purposes the funds available and necessary for education. But if the won $\mathrm{k}$ is to be successfully carried out, it is essential that the Technical Instruction Committees should have entire control of the grants allocated to technical education. There is far too much uncertainty about the grants even now, and the County Cou'sils which are inclined to exer cise a veto as to the destination of the surplus funds of their Technical Education Committees, will soon find that selfrespecting members of the Comm ttees will retire from the work. Recently, however, one or two Councils have shown their incapacity to understand the magnitude of the problem before them. by voting the unexpended balance of their grants to the relief of rates. This action is tantamount to declaring that the funds at the disposal of the Committee are in excess of what is required; whereas, it is hardly too much to say that additional secondary schools are needed in almost evary county and county borough in England, only to mention one way in which the money might be expended. For the balance to be diverted from education is bad enough, but no great foresight is needed to see that, once the action has been taken, there is no knowing where or when it will stop. Perhaps the county of Hampshire is the most notable instance in which a County Council has crippled the work of its Technical Instruction Committee. In November last, according to the Southampton Times, the Council resolved to appropriate, for general purposes, $£ 6000$ from the surplus funds which had been accumulated by the Technical Instruction Committee with the idea of eventually using it in educational developments. Without taking the views of the Committee into consideration, the Council appears to have calmly confiscated the balance resulting from economical administration, and by sodoing not only discouraged careful expenditure, but in one fell swoop rendered the Committee powerless to deal in the future with matters which alone could be met by exceptional means. Surely it is not too much to expect a Council to have confidence in the ability of the Technical Instruction Committee, and to allow it to know i:s own needs. At any rate, a Committee whose opinion is disregarded must soon lose cunfidence in itself. It is a matter for congratulation that County Councils genetally have not treated their Committees in the same way as the elect of the county of Hampshire.

One of the most refreshing repor $s$ we have seen for some time has recently been issued by the Derbyshire County Council. The report is satisfactery, not so much on account of wo k accomplished, but because it affords evidencs that the Commit ee seems to have been brought to a good understanding as to what technical instruction should mean. One of the chief difficultie 
met with in most parts of the country arises from the suspicion with whicb the spoilt "praclical man" regards the whole scheme of education designed to benefit him. No class harbours this prejudice more than farmers and their labourers. Almost every local authority complains of the apathy, or the opposition, of agriculturists to the extension of knowledge in the scientific principles of agriculture. When the Derbyshire Committee approached this branch of their work, they hesitated to establish agriculture classes under the auspices of the Department of Science and Art, because such classes are open to undesirable ob. jections from this section of the community. In the first place, there is an appearance of attempting to teach "farming" in the lecture-room, and secondly, the teachers who are qualified to give most of the information cortained in the Science and Art syllabus, are usually not actually engaged in the agricultural industry itself. Both these difficulties have been cleverly met by the Committee in this way :- "In place of the "Agriculture' Classes of the Science and Art Department, the Committee are anxious that the students in rural evening schools shall go through a course of elementary science, which shall be of a very simple but thoroughly scientific nature. It is intended that the student shall be taught by actual experiment, and shall thus come to appreciate that the results of science are not fanciful, but are conclusions drawn from a study of actual facts. The phenomena studied in this course of lessons are of a general character, but are also largely chosen from the domain of agriculture, so that without any suspicion that the schoolmaster is attempting to teach 'farming,' the student learns a number of principles which cannot fail to affect him in practice.

"The great merits of this scheme of teaching elementary science in rural evening schools in place of starting Science and Art Department 'Agriculture' Classes are that the students are kept together year a'ter year, studying other subjects which go to make up the curriculum, the Elenentary Science course extending over two or three years, so that a first set of pupils is ready when the older ones have passed through; and further, there is no suspicion of teacbing what can only be learned on the farm."

The scheme is very attractive, and good results may be expected from its application in Derbyshire. It enforces the fact that a knowledge of the elementary principles of science is the only sound basis upon which to build courses of technology.

The county of Derby is more dependent upon the mining industry than on any other; therefore its organisation of instruction in mining deserves a word of remark. It attempted to provide the instruction by means of courses of lectures delivered in a certain number of pit villages, but the results were hardly successful. The teaching was afterwards given by local men who had practical knowledge of mining, and some acquaintance with collateral branches of science, and this scheme was more satisfactory than the former. The point to be borne in mind in all such cases is that chemistry, steam, geology, some branches of physics, and mechanical drawing should form a part of the education of every mining student. With reference to local teachers, a word may be necessary. There is, of course, a tendency in many districts to patronise local ability, but it should always be borne in mind that the local man is not of necessity the man who will do best. In the expenditure of public money, it ought to be a guiding principle that the best teachers available by advertisement and good salaries should always be selected.

The evergreen complaint of Technical Education Committees finds expression in the report from Derbyshire. In connection with the subject of evening continuation schools, we read : "The Comnittee have found that one of the great difficulties which the ordinary student experiences in receiving instruction in every kind of technical subject is the lack of sutficient preliminary knowledge. His elementary school education has very largely leaked away, instead of having been continued to the point giving easy comprehension of scientific principles and problems. This implies that the national expenditure on elementary education is very largely wasted without some supplementary scheme by which the instruction given shall be conserved and continued until the student is old enough to grasp its importance." This puts the whole matter in a nutshell. When the average boy leaves the elementary school, at about fourteen years of age, he regards his education as completed, with the result that he has no interest whatever in schools or classe of any educational value. Committees must not hope to attract the majority of working lads into evening continuation schools, however diversified their prospectuses may be. Only here and there can pupils be found who have begun to see the depths of their ignorance, but these are the minds to nurture, and for their benefit systems of evening-classes should be constructed.

Before the era of the County Councils, the principal means for the spread of instruction in elementary science was undoubtedly the classes of the Science and Art Department. Testimony is borne to this in the report referred to. We read :

"It has been the custom in many educational quarters to criticise and cundemn the methods of that Department, and to create an impression that but little good has been accomplished. The contrary of this is undoubtedly the case. In all manufacturing centres it will be found that there are numbers of persons applying 10 every kind of industry scientific principles and knowledge gained at Science and Art Classes, and which could not have been gained anywhere else during the last thirty-five years." The Department is very well able to take care of itself, but this statement of fact may be profitably considered by those who disparage its tisefulness.

If there is one thing our educational system lacks more than ano her, it is proper facilities for secondary education. Recognising that a good education in a secondary school is the only means by which the hishest branches of technical instruction could be approached, the Derbyshire Committee offered for competition sixty scholarships tenable at secondary schools. After the awards had been made, it was found that only six out of the sixty successful candidates chose schools in the county, and that there was only one school in the adminis. trative county available for the girls who had won scholarships. An inspection of the Grammar Schools, and similar institutions in the county, with a view to determining their educa ional conditions and needs, revealed a general want of proper equipment ; indeed, only one out of nine secondary schools had a chemical laboratory. Derbyshire is certainly not alone in this deplorable state of things, which it will take some years to im. prove. The fact that the defects in our educational system are being exposed, and that attempts are being made to meet them fairly, is a clear promise of progress. If the Technical In. struciion Committees had done no more than reveal the inefficiency and insufficiency of scientific instruction in the counties of Envland, they would have furthered the interesis of science. But as they have also helped to organive and increase the facilities for such instruction, they have worked in no mean way for the extension of natural knowledge. En ouragement and friendly guidance is all that is required to render the work even more valuable in the future than it has been in the past.

\section{R. A. GREGORY.}

\section{SCIENCE IN THE MAGAZINES.}

FIRST in importance among the contributions to the February magazines is a collection of opinions on forest preserva. tion, published in the Century. In response to a request from the editor of that magazine, a number of persons interested in arboriculture sent their views as to the general need of a thorough, scientific, and permanent system of furest management in the United States, and specifically as to the plan suggested by Prof. C. S. Sargent, which comprised the following features:-

(I) Forestry instruction at West Point; the establishment of a chair of Forestry at the United States Military Academy, to be supplemented by practical study in the woods and by personal iuspection of foreign systems of forestry.

(2) An experimental forest reservation; the purchase on the Highlands near West Point, or elsewhere, of a small territory for the use of the proposed new branch of instruction.

(3) Control by educated officers; the assignment of the best educated of these officers to the supervision of the forest reservations.

(4) The enlistment of a forest guard; a body of local foresters, to be specially enlisted for the purpose of carrying out the principles of forestry thus taught.

The experts consulted agree in the opinion that the United States needs a thoroughly scientific and permanent system of forest management in the interests of the people of to-day, and of future generations. But the general feeling seems to be that the management of the forests should not be placed under any military organisation. As to the suggestion to inc ease the curriculum of the U.S. Military Academy so as to cover

NC. I 320 , VOL. $5 \mathrm{I}]$ 